\title{
PENGARUH STRATEGI MASS CUSTOMIZATION TERHADAP KINERJA PERUSAHAAN MELALUI PENGGUNAAN KARAKTERISTIK INFORMASI SISTEM AKUNTANSI MANAJEMEN (STUDI EMPIRIS PADA PERUSAHAAN BIRO WISATA DI KOTA BANDA ACEH)
}

\author{
Tria Ulfa ${ }^{1}$, Fazli Syam BZ ${ }^{* 2}$ \\ ${ }^{1,2}$ Program Studi Akuntansi Fakultas Ekonomi dan Bisnis Universitas Syiah Kuala \\ e-mail: triaulfa26@gmail.com ${ }^{1}$, fazlisyambz@unsyiah.ac.id ${ }^{2}$
}

\section{* Corresponding Author}

\begin{abstract}
Abstrak
This study aims to (1) Analyze the effect of the application of mass customization strategies on company performance through the characteristics of management accounting system that are broad scope, (2) Analyze the effect of applying mass customization strategies to company performance, (3) Analyze the effect of applying mass customization strategies to the use of management accounting system information that is broad scope, (4) Analyzing the effect of the use of management accounting information systems that are broad scope on company performance. The population of this research is 126 travel companies in Banda Aceh. The sampling technique in this study was using purposive sampling techniques. This research is a study that uses primary data for his research. Primary data obtained through the distribution of questionnaires to respondents. In this study data analysis will be carried out using path analysis. The conclusions generated from this study are (1) Indirectly mass customization through the characteristics of management accounting system information has a greater positive influence on company performance, (2) Mass customization strategies have a positive influence on company performance, (3) Mass customization strategies provide positive influence on the characteristics of management accounting system information, (4) Characteristics of information management systems that are broadscope that have a positive influence on company performance.
\end{abstract}

Keywords: mass customization, company performance, broad scope

\section{Pendahuluan}

Di era modern ini, wisata merupakan suatu kebutuhan bagi setiap golongan masyarakat. Di beberapa negara bahkan setiap karyawan suatu perusahaan diberikan tunjangan dan diwajibkan untuk berwisata guna menunjang kinerja karyawan itu sendiri. Banyak hal yang bisa dijadikan sebagai objek wisata dengan harga dan fasilitas yang bervariasi. Halhal yang dapat dijadikan sebagai objek wisata antara lain alam, tempat rekreasi, bahkan ada pula tempattempat yang dianggap ekstrem yang bisa dijadikan sebagai objek wisata.

Sektor pariwisata merupakan sektor bisnis yang sedang gempar-gemparnya di era globalisasi ini. Salah satu aspek yang memicu kemajuan negara Indonesia merupakan aspek pariwisata, dimana Indonesia sangat kaya akan keindahan alamnya. Di era globalisasi ini, para turis dari dalam negeri dan juga dari luar negeri, berlomba-lomba untuk bisa menikmati keindahan alam Indonesia. Sehingga industri pariwisata berlombalomba pula untuk menawarkan produk wisata terbaik serta pelayanan terbaik bagi konsumen.

Adapun permasalahan yang sering dihadapi oleh pengusaha biro wisata adalah permintaan dan selera setiap konsumen yang berbeda-beda. Terkadang pihak biro wisata bahkan bisa rugi jiika konsumen meminta pelayanan yang tidak masuk dalam anggaran atau dalam biaya pokok jasa. Oleh karena itu, ini sudah menjadi masalah utama yang harus dilalui agar kinerja perusahaan tidak terganggu.

Kondisi yang seperti ini membuat perusahaan untuk merancang operasional sebaik mungkin dan seefektif mungkin, karena keberhasilan perusahaan juga ditentukan oleh kepuasan konsumen itu sendiri. Dengan adanya kemajuan teknologi, permintaan konsumen terhadap suatu produk atau jasa juga 
bermacam-macam, sehingga perusahaan juga memiliki kewajiban untuk memenuhi kebutuhan konsumen agar profiabilitas perusahaan tetap terjaga. Setiap wisatawan yang ingin membeli paket wisata pasti memiliki keinginannya masing-masing menyangkut fasilitas-fasilitas yang akan diberikan oleh pihak biro wisata selama perjalanan wisata tersebut berjalan. Dengan adanya selera dan permintaan konsumen yang beragam tersebut, maka pihak biro wisata harus menyesuaikan tingkat harga yang ditawarkan dengan fasilitas atau layanan yang akan diberikan sesuai dengan keinginan konsumen. Strategi tersebut disebut dengan strategi mass customization.

Oleh sebab itu, perusahaan biro wisata harus melakukan pengukuran kinerja perusahaan mereka atas strategi mass customization yang mereka terapkan melalui informasi Sistem Akuntansi Manajemen (SAM). Hal ini akan membantu perusahaan tersebut dalam memantau kinerja perusahaan mereka agar kinerja perusahaan mereka tidak menurun. Turunnya kinerja perusahaan akan berdampak pada konsumen serta tingkat penjualan perusahaan kedepannya.

Menurut Setiawan (2015), strategi customization memiliki dampak bagi para pengguna atau yang memanfaatkan informasi SAM, serta penggunaan karakteristik informasi SAM berpengaruh atas tingkat kinerja perusahaan. Dalam hal ini, informasi SAM merupakan sebagai variabel intervening. Menurut Walker, Fleischman, \& Johnson (2012), perusahaan harus memasukkan informasi SAM sebagai ukuran kinerja utama dari fungsi akuntansi. Menurut Chenhall dan Morris (1986) dalam Ghasemi (2016), informasi yang disediakan SAM dapat dianggap berdasarkan empat karakteristik informasinya yaitu broad scope, integration, timelines, dan agregation.

Setiap manajer tentu membutuhkan informasi yang bersifat umum dan lengkap. Namun, manajer juga membutuhkan informasi yang mendukung lebih luas dan lengkap yang memenuhi ciri-ciri informasi tersebut. Bagi perusahaan sederhana seperti perusahaan biro wisata karakteristik informasi SAM yang lebih berperan dalam proses produksi hanya broad scope. Informasi SAM yang lebih sesuai dan relevan dengan keadaan serta yang dibutuhkan perusahaan adalah karakteristik informasi SAM yang bersifat broad scope, dimana karakteristik tersebut sudah mewakili horizon waktu, kuantifikasi, dan juga dimensi fokus (Gordon \& Narayanan, 1984).

Informasi yang bersifat broad scope juga adalah informasi yang sangat dibutuhkan dan berperan penting dalam mengambil keputusan dan juga sebagai variabel penting dalam peningkatan kinerja perusahaan (Mia \& Chenhall, 1994). Oleh sebab itu, karakteristik informasi SAM dalam penelitian ini lebih fokus pada karakteristik informasi SAM yang bersifat broad scope.

Berdasarkan latar belakang yang telah diuraikan tersebut, maka penulis mengajukan penelitian dengan judul "Pengaruh Strategi Mass Customization terhadap Kinerja Perusahaan melalui Pengunaan Karakteristik Informasi Sistem Akuntansi Manajemen (Studi Empiris pada Perusahaan Biro wisata di Kota Banda Aceh)". Penelitian ini menganalisis permasalahan tentang seberapa pengaruhnya penerapan mass customization pada kinerja perusahaan melalui informasi SAM yang terjadi pada perusahaan biro wisata.

Berdasarkan latar belakang yang telah dipaparkan sebelumnya, permasalahan yang timbul dalam penelitian ini dirumuskan sebagai berikut:

1. Apakah penerapan startegi mass customization berpengaruh pada kinerja perusahaan melalui karakteristik informasi SAM yang bersifat broad scope.

2. Apakah penerapan stategi mass customization berpengaruh terhadap kinerja perusahaan.

3. Apakah penerapan strategi mass customization berpengaruh terhadap penggunaan karakteristik informasi SAM yang bersifat broad scope.

4. Apakah penggunakan karakteristik informasi SAM yang bersifat broad scope berpengaruh pada kinerja perusahaan.

Ada beberapa tujuan utama dari penelitian ini, yaitu sebagai berikut:

1. Menganalisis pengaruh penerapan strategi mass customization terhadap kinerja perusahaan melalui karakteristik informasi SAM yang bersifat broad scope.

2. Menganalisis pengaruh penerapan strategi mass customization terhadap kinerja perusahaan.

3. Menganalisis pengaruh penerapan strategi mass customization terhadap penggunan karakteristik informasi SAM yang bersifat broad scope. 
4. Menganalisis pengaruh penggunaan karakteristik informasi SAM yang bersifat broad scope pada kinerja perusahaan.

\section{Kerangka Teoritis Dan Pengembangan Hipotesis}

\section{Tinjauan Pusataka}

\section{Strategi Mass Customization}

Mass customization merupakan suatu teknik dalam proses manajemen dimana dalam proses pemasaran dan juga proses produksi direncanakan dan dilakukkan dengan sangat baik sehingga menjadi solusi dalam peningkatan variasi kebutuhan pelanggan (Hery, 2014:121). Banyak perusahaan manufaktur dan jasa menghadapi permasalahan yang sama seperti pelanggan mengharapkan produk atau jasa yang khusus dikembangkan untuk setiap pelanggan.

Menurut Gilmore \& Pine (1997) dalam Setiawan (2015) customization merupakan suatu strategi yang digunakan untuk merespon permintaan konsumen agar peningkatan variasi produk atau jasa yang lebih khusus dan lebih berkualitas. Mass customization adalah suatu strategi yang digunakan oleh perusahaan guna menghasilkan produk yang atau jasa yang sesuai dengan permintaan pelanggan secara individu, tetapi tetap dengan efisiensi produksi (Pine, 1993 dalam Setiawan, 2015).

\section{Karakteristik Informasi Sistem Akuntansi Manajemen}

SAM adalah suatu sistem yang bertugas untuk menghimpun data, baik data operasional maupun data finansial. Selanjutnya data tersebut akan diproses serta disimpan, dan kemudian menghasilkan laporan kepada para pengguna, seperti pihak karyawan, manajer, dan bagian eksekutif perusahaan (Atkinson dkk, 2001 dalam Ernawati, 2005). SAM juga dapat dibentuk guna menyediakan informasi yang handal serta dapat membantu mengawasi dan mengkoordinasikan dalam berbagai departemen perusahaan (Nazaruddin dan Fajry, 2005). Informasi yang disediakan SAM dapat dianggap berdasarkan empat karakteristik informasinya yaitu broad scope, integration, timelines, dan agregation. Karakteristik informasi SAM yang digunakan dalam penelitian ini hanya broad scope.

Informasi SAM yang bersifat broad scope tercakup di dalamnya informasi yang berkaitan dengan yang bersifat ekonomi ekonomi (total penjualan, pangsa pasar dan produk nasional bruto), informasi non ekonomi (kemajuan teknologi, perubahan sosial, pengembangan demografi), yang berkaitan dengan lingkungan eksternal perusahaan dan memberikan informasi berkaitan dengan prediksi tentang peristiwa yang mungkin akan terjadi pada masa yang akan datang. Informasi SAM yang bersifat broad scope ini mencakup dimensi fokus, horizon waktu, dan kuantifikasi (Syam, Azzumar, \& Zuraida, 2018).

\section{Kinerja Perusahaan}

Kinerja adalah hasil yang didapatkan oleh suatau perusahaan, baik perusahaan yang berorientasi laba maupun perusahaan yang berorientasi nirlaba (Fahmi, 2010:2). Kinerja adalah sebuah kegiatan yang diterapkan dan dilakukan guna memberi penilaian terhadap pekerjaan yang telah dikerjakan oleh individu dengan cara membuat perbandingan kinerja individu tersebut dengan mendeskripsikan dan menguraikan pekerjaan dalam suatu waktu tertentu (Eliana, 2015). Pengukuran kinerja harus dilakukan guna mengetahui deviasi selama melaksanakan kinerja dari rencana yang telah dilakukan sebelumnya, memastikan apakah kinerja dilaksanakan sesuai dengan waktu yang ditentukan, dan memastikan apakah kinerja sudah mencapai target yang diharapkan perusahaan (Wibowo, 2007:155).

\section{Penelitian Terdahulu}

Pada penelitian yang dilakukan oleh Edwin Setiawan (2015) menyimpulkan bahwa strategi customization tidak berpengaruh terhadap kinerja perusahaan, sedangkan strategi customization berpengaruh terhadap kinerja perusahaan melalui penggunaan karakteristik informasi SAM. Pada penelitian yang dilakukan oleh Syafira Ramadhea JR (2013) menyimpulkan bahwa strategi mass customization tidak berpengaruh signifikan positif terhadap kinerja perusahaan. Sedangkan strategi mass customization berpengaruh signifikan positif terhadap kinerja perusahaan melalui penggunaan karakteristik informasi SAM yang bersifat broad scope. Pada penelitian yang dilakukan oleh Abu Nizarudin (2006) menyimpulkan bahwa informasi broad scope dan agregation dapat mengontribusikan inovasi baru dalam membuat keputusan operasional dan menimbulkan ide baru dalam menghasilkan produk. Pengaruh strategi customization terhadap kinerja 
perusahaan dimediasi oleh broad scope dan aggregation.

\section{Kerangka Pemikiran}

\section{Pengaruh Strategi Mass Customization terhadap Kinerja Perusahaan melalui Karakteristik Informasi Sistem Akuntansi Manajemen yang Bersifat Broad Scope}

Pada persaingan pasar yang sangat ketat ini, perusahaan akan menghadapi tantangan-tantangan yang lebih sulit untuk diselesaikan. Dengan adanya perluasan market share, akan mengakibatkan perusahaan lebih mementingkan kepentingan costumer. Oleh karena itu, perusahaan mencari solusi untuk bisa memenuhi segala kebutuhan konsumen. Salah satu strategi yang diterapkan demi memenuhi kebutuhan konsumen adalah strategi mass customization. Melalui strategi ini, perusahaan akan mampu merespon kebutuhan konsumen dalam melakukan produsi barang dan jasa yang bervariasi. Mass customizatin merupakan variabel yang harus dipertimbangkan dalam merancang SAM guna menigkatkan kinerja perusahaan (Setiawan, 2015).

Informasi SAM sangat berguna bagi perusahaan dalam mencapai tujuan perusahaan. Memenuhi kebutuhan manajemen berupa informasi dan mengkoordinasi kinerja antara subunit fungsional merupakan kepuasan tersendiri bagi manajer. Dengan diterapkannya strategi mass customization ini mungkin akan memberikan dampak atau pengaruh terhadap kinerja perusahaan. Oleh karena itu, para manajer perusahaan membutuhkan informasi SAM demi mengawasi kinerja perusahaan. Dengan diterapkannya strategi mass customization ini diharapkan akan memberikan dampak yang baik terhadap tingkat kinerja perusahaan melalui informasi SAM (JR, 2013).

Hasil penelitian Setiawan (2015) dan JR (2013) menunjukkan bahwa penerapan strategi mass customization memberikan pengaruh yang signifikan terhadap kinerja perusahaan melalui informasi SAM yang bersifat broad scope. Sedangkan dalam penelitian Nizarudin (2006) menunjukkan bahwa penerapan strategi mass customization memberikan pengaruh yang signifikan terhadap kinerja perusahaan melalui informasi SAM yang bersifat broad scope dan agregation.

\section{Pengaruh Strategi Mass Customization terhadap Kinerja Perusahaan}

Costumization merupakan suatu strategi yang gunakan untuk merespon permintaan pelanggandalam membuat produk atau jasa yang bervariasi serta berkualitas (Gilmoredan Pine, 1997 dalam Setiawan, 2015). Pengukuran kinerja yang tepat dapat dilakukan dengan beberapa cara, salah satunya adalah memastikan bahwa persyaratan sesuai dengan keinginan pelanggan telah terpenuhi (Wibowo, 2007:155). Dengan menggunakan strategi mass customization perusahaan dapat memberikan pelayanan yang lebih baik sehingga akan memberikan pengaruh terhadapat kinerja perusahaan menjadi lebih baik (Kekre dan Srinivasan, 1990 dalam Nizarudin, 2006).

Banyak perusahaan manufaktur dan jasa menghadapi permasalahan yang sama, yaitu pelanggan mengharapkan produk atau jasa yang khusus dikembangkapn untuk setiap pelanggan. Mass customization merupakan strategi yang dihapakan bisa memberikan pengaruh terhadap kinerja perusahaan. Dalam penelitian JR (2013), Setiawan (2015), dan Nizarudin (2006) menunjukkan bahwa strategi mass customization tidak memberikan pengaruh atas kinerja perusahaan. Namun, pada penelitian sebelumnya, yaitu pada penelitian Balakrishnan (1996) strategi mass cutomizatin dapat berpengaruh terhadap atas perusahaan.

\section{Pengaruh Strategi Mass Customization terhadap} Karakteristik Informasi Sistem Akuntansi Manajemen yang Bersifat Broad Scope

Menurut JR (2013), sistem informasi memiliki peran yang begitu penting dalam peningkatan ketidakpastian hubungan antara input dengan output dalam suatu bagian atau departemen menggunakan strategi mass customization. Informasi SAM sangat diperlukan dan juga dibutuhkan oleh para manajer dalam mencari serta menemukan pemikiran atau ideide terbaru guna memproduksi produk-produk terbarunya. Informasi SAM bisa menimbulkan peningkatan total alternatif sebagai bahan pertimbangan manajer dalam pengambilan keputusan secara simultan yang berhubungan dengan input serta output yang tidak pasti (Setiawan, 2015).

Karakteristik informasi SAM yang digunakan dalam penelitian ini adalah karakteristik yang bersifat 
broad scope. Informasi yang bersifat broad scope sangat dibutuhkan oleh manajer guna menemukan dan menentukan inovasi-inovasi bagaimana dapat membuat produk baru atau jasa baru. Menurut bouwens (1998) dalam Nizarudin (2006), jumlah alternatif yang akan menjadi bahan pertimbangan akan meningkat dengan adanya informasi SAM yang bersifat broad scope dengan simultan saat membuat keputusan yang memiliki hubungan dengan ketidakpastian output dan input.

Oleh karena itu, dapat ditarik kesimpulan bahwa karakteristik informasi SAM yang bersifat broad scope sangat diperlukan saat suatu perusahaan menerapkan strategi mass customization. Pelaksanaan strategi mass customization akan menimbulkan sebuah tantangan tersendiri di bidang manajemen dalam hal merancang informasi serta struktur yang tepat (Setiawan, 2015). Dalam penelitian-penelitian tersebut menyimpulkan bahwa strategi mass customization berpengaruh positif terhadap informasi SAM yang bersifat broad scope.

\section{Pengaruh Karakteristik Informasi Sistem Akuntansi Manajemen yang Bersifat Broad Scope terhadap Kinerja Perusahaan}

Informasi SAM sangat membantu bagi pihak perusahaan dalam menghadapi berbagai rintangan dan tantangan pasar yang sangat kompetitif serta dapat membantu para manajer memantau kinerja perusahaan.Informasi yang diberikan oleh SAM dalam teori teknis rasional, terutama dalam organisasi pemerintah, dapat membantu alokasi sumber daya secara efisien dan efektif (Houge, 2003 dalam Indriani \& Nadirsyah, 2015). SAM adalah bagian, struktur, dan organisasi dari unsur-unsur yang membentuk sistem pengendalian manajemen (Simons, 1990 dalam Indriani \& Nadirsyah, 2015).

Manajer terkadang tidak menyadari menurunnya kinerja perusahaan, sehingga perusahaan terlanjur masuk ke dalam zona krisis yang dianggap serius. Oleh karena itu, dibutuhkan strategi-strategi oleh manajer untuk menghindari kondisi tersebut. Salah satu strategi tersebut adalah adanya sebuah sistem informasi yang teratur dan terintegrasi dengan sebaik mungkin. Informasi tersebut tentu sangat berguna bagi para manajer guna menjalankan proses perencanaan, pengawasan, dan pengambilan keputusan. Informasi tersebut adalah informasi SAM (Ayu \& Dahen, 2014).
Karakteristik informasi SAM yang bersifat broad scope akan memberikan informasi tentang faktor eksternal dan internal perusahaan, ekonomi dan non-ekonomi, perkiraan peristiwa masa depan (Syam et al., 2018).MenurutMia \& Chenhall (1994), karakteristik informasi SAM yang dapat diandalkan akan memberikan peningkatan terhadap kinerja perusahaan. menurut Chia (1995) dalam Nizaruddin (2006) dengan tingginya tingkat desentralisasi, penggunaan karakteristik SAM yang bersifat andal akan memberikan peningkatan pula terhadap kinerja perusahaan.

Penelitian tentang pengaruh strategi informasi SAM yang bersifat broad scope terhadap kinerja perusahaan telah diteliti sebelumnya oleh bebrapa peneliti, antara lain Abu Nizarudin (2006), Syafira Ramadhea JR (2013), Edwin Setiawan (2015), Gusti Ayu (2014), dan Fazli Syam (2018). Semua hasil dari penelitian-penelitian tersebut menyimpulkan bahwa strategi informasi SAM yang bersifat broad scope berpengaruh positif terhadap kinerja.

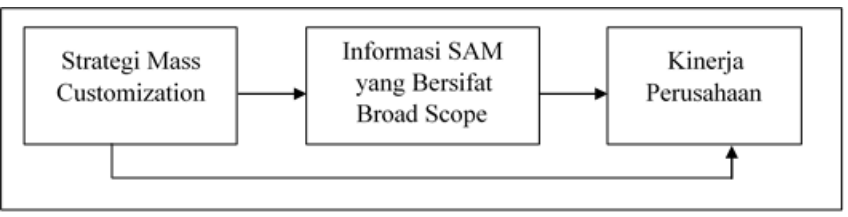

Gambar 2.1

\section{Skema Kerangka Pemikiran}

\section{Hipotesis}

Berdasarkan kerangka pemikiran yang telah dijelaskan sebelumnya, maka dapat ditarik hipotesis sebagai berikut:

H1: Strategi mass customization memberikan pengaruh positif terhadap kinerja perusahaan melalui karakteristik informasi SAM yang bersifat broad scope.

$\mathrm{H} 2$ : Strategi mass customization memberikan pengaruh positif terhadap kinerja perusahaan.

H3: Strategi mass customization memberi pengaruh positif terhadap karakteristik informasi SAM yang bersifat broad scope.

H4: Karakteristik informasi SAM yang bersifat broad scope memberikan pengaruh positif terhadap kinerja perusahaan. 


\section{Metode Penelitian \\ Desain Penelitian}

Penelitian ini merupakan penelitian kuantitatif, yaitu penelitian yang dirancang dengan menggunakan prosedur statistika atau dengan menggunakan metode kuantifikasi lainnya guna mengukur variabel yang ada dalam penelitian. Penelitian ini adalah penelitian jenis studi kausal. Tujuan studi dalam penelitian ini adalah pengujian hipotesis. Penelitian ini memberi penjelasan mengenai pengaruh strategi mass customization terhadap kinerja perusahaan melalui informasi SAM yang bersifat broad scope. Tingkat intervensi dalam penelitian ini adalah minimal dengansituasi studi tidak diatur tidak diatur. Strategi penelitian ini merupakan penelitian survei. Horizon waktu dalam penelitian ini adalah cross sectional. Unit analisis dalam penelitian ini adalah pemilik ataumanajer perusahaan.

\section{Populasi dan Sampel}

Populasi perusahaan biro wisata di Banda Aceh adalah sebanyak 126 perusahaan. Dari populasi tersebut akan diambil beberapa sampel yang akan dijadikan sebagai objek penelitian. Teknik pengambilan sampel dalam penelitian ini yaitu menggunakan teknik pengambilan sampel bertujuan (purposive sampling).

Oleh karena penelitian ini menggunakan teknik puposive sampling, maka peneliti telah menentukan kriteria yang akan digunakan dalam pengambilan sampel tersebut. Kriteria tersebut adalah sebagai berikut:

1. Perusahaan biro wisata yang telah berjalan minimal sejak tahun 2016.

2. Perusahaan biro wisata tersebut menjual paket wisata baik dalam negeri maupun luar negeri dan atau menjual paket umrah.

Berdasarkan uraian di atas, dapat disimpulkan bahwa sampel yang akan digunakan sebagai sampel penelitian adalah sebanyak 33 perusahaan biro wisata.

\section{Metode Pengumpulan Data}

Penelitian ini merupakan penelitian yang memakai data primer untuk penelitiannya. Data primer yang diperoleh memalui pembagian kuesioner kepada responden. Responden penelitian ini adalah manajer atau pemilik perusahaan biro wisata di Banda Aceh. Daftar pertanyaan disediakan secara terstruktur yang diajukan kepada responden. Untuk menghindari rendahnya tingkat respon, langkah yang diambil adalah dengan dengan mengantarkan langsung kuesioner kepada responden dan menghubungi kembali guna mengingatkan dan memastikan responden untuk melakukan pengisisian kuisioner yang telah diberikan. Setelah itu, dikumpulkan kembali dengan cara dijemput kuisioner yang telah diisi dengan cara menjemputnya ke lokasi responden.

\section{Operasionalisasi Variabel}

\section{Tabel 3.3}

\section{Operasionalisasi Variabel}

\begin{tabular}{|c|c|c|c|}
\hline Variabel & Indikator & Skala & Sumber \\
\hline $\begin{array}{l}\text { Strategi Mass } \\
\text { Customization }\end{array}$ & $\begin{array}{l}\text { 1. Model jasa } \\
\text { yang } \\
\text { dihasilkan, } \\
\text { 2. Kesesuaian } \\
\text { model jasa } \\
\text { dengan } \\
\text { permintaan } \\
\text { konsumen, } \\
\text { 3. ketepatan } \\
\text { waktu }\end{array}$ & $\begin{array}{l}\text { Interval } \\
\text { diukur } \\
\text { dengan } \\
\text { skala } \\
\text { Likert }\end{array}$ & $\begin{array}{l}\text { Setiawan } \\
(2015)\end{array}$ \\
\hline $\begin{array}{l}\text { Karakteristik } \\
\text { Informasi } \\
\text { Sistem } \\
\text { Akuntansi } \\
\text { Manajemen } \\
\text { yang bersifat } \\
\text { broad scope }\end{array}$ & $\begin{array}{l}\text { 1. Informasi } \\
\text { eksternal } \\
\text { yang } \\
\text { bersifat } \\
\text { ekonomi, } \\
\text { 2. Informasi } \\
\text { eksternal } \\
\text { yang } \\
\text { bersifat } \\
\text { non } \\
\text { ekonomi }\end{array}$ & $\begin{array}{l}\text { Interval } \\
\text { diukur } \\
\text { dengan } \\
\text { skala } \\
\text { Likert }\end{array}$ & $\begin{array}{l}\text { Ayu dan } \\
\text { Dahen } \\
(2014)\end{array}$ \\
\hline $\begin{array}{l}\text { Kinerja } \\
\text { Perusahaan }\end{array}$ & $\begin{array}{l}\text { 1. Hasil yang } \\
\text { dihasilkan } \\
\text { 2. Pelayanan } \\
\text { yang } \\
\text { diberikan } \\
\text { 3. Kualitas } \\
\text { pelayanan } \\
\text { 4. Hasil yang } \\
\text { dibandingk } \\
\text { an dengan } \\
\text { tujuan } \\
\text { yang ingin } \\
\text { dicapai }\end{array}$ & $\begin{array}{l}\text { Interval } \\
\text { diukur } \\
\text { dengan } \\
\text { skala } \\
\text { Likert }\end{array}$ & $\begin{array}{l}\text { Setiawan } \\
\text { (2015) }\end{array}$ \\
\hline
\end{tabular}




\section{Metode Analisis}

Dalam penelitian ini analisis data akan dilakukan dengan menggunakan snalisis jalur (path analysis) guna menganalisis tingkat besarnya suatu vaiabel independen mempengaruhi variabel dependen. Variabel strategi mass customization (X) berperan sebagi variabel independen memperngaruhi kinerja perusahaan (Y) sebagai variabel dependen melalui karakteristik informasi SAM bersifat broad scope sebagai variabel intervening ( $Z$ ). Sehingga $X$ mempengaruhi $\mathrm{Z}$, kemudian $\mathrm{Z}$ mempengaruhi $\mathrm{Y}$.

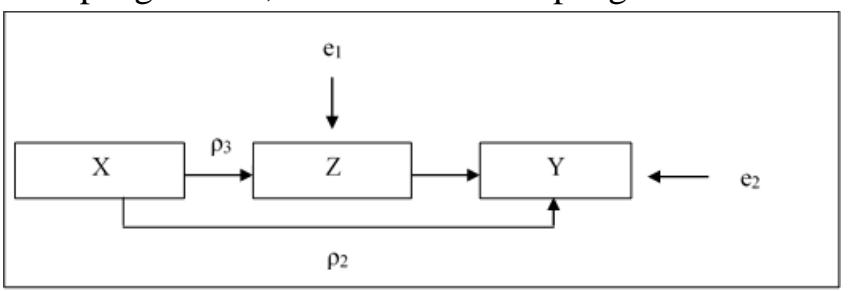

Gambar 3.1

Model Analisis Jalur

\section{Hasil Dan Pembahasan}

Dari seluruh jumlah kuesioner yang dibagikan kepada responden, selutuh kuesioner tersebut tingkat pengembaliannya sebesar $100 \%$.

\section{Karakteristik Responden Penelitian}

Banyaknya yang berjenis kelamin laki-laki lebih dominan dibandingkan responden perempuan. Dari segi pendidikan terakhir dapat dilihat banyaknya responden yang berpendidikan terakhir D3 juga sama jumlahnya dengan jumlah responden yang berpendidikan terakhir SMA, yaitu sebanyak 30,3\%. Jumlah responden yang berpendidikan terakhir S1 ada sebanyak 33,3\%. Sisanya adalah responden yang berpendidikan lain-lain (S2) ada sebanyak atau 6,1\%. Dari segi jabatan responden dapat dilihat bahwa responden yang memiliki jabatan sebagai pemilik perusahaan lebih unggul dibandingkan dengan responden yang berjabatan sebagai maajer perusahaan.

Berdasarkan umur perusahaan dapat dilihat bahwa perusahaan yang berumur 2-5 tahun ada sejumlah $24,2 \%$. Perusahaan yang berumur 5-10 tahun ada sejumlah $42,4 \%$. Sisanya adalah perusahaan yang berumur $>10$ tahun ada sejumlah $33,3 \%$.

\section{Hasil Pengujian Kualitas Data Hasil Uji Validitas}

Berdasarkan hasil pengujian dapat dilihat bahwa seluruh varia dalam penelitian ini dapat dikatakan valid. Hal ini dapat dibuktikan dengan nilai korelasi lebih besar daripada nilai kritis sebesar 0,344. Jadi semua item pertanyaan yang ada dalam koesioner penelitian ini dianggap valid dengan tingkat signifikan $50 \%$.

\section{Hasil Pengujian Reliabilitas}

Berdasarkan hasil pengujian menggambarkan bahwa koefisien cronbach alpha yaitu lebih besar dari 0,60 . Oleh sebab itu dapat disimpulkan bahwa kuesioner dapat digunakan sebagai alat dalam mencapai tujuan penelitian ini.

\section{Hasil Pengujian Hipotesis \\ Hipotesis 1}

Tabel 4.11

Hasil Analisis Regresi Pengaruh Strategi Mass Customization Terhadap Kinerja Perusahaan Melalui Karakteristik Informasi SAM

\begin{tabular}{|c|c|c|c|c|c|c|}
\hline Variabel & B & $\begin{array}{l}\text { Std. } \\
\text { Error }\end{array}$ & $t_{\text {hitung }}$ & Sig. & $\mathrm{R}$ & $\begin{array}{c}\mathrm{R} \\
\text { square }\end{array}$ \\
\hline $\begin{array}{l}\text { Mass } \\
\text { Customi } \\
\text { zation }\end{array}$ & $\begin{array}{c}0,25 \\
8\end{array}$ & 0,130 & 1,924 & $\begin{array}{c}0,06 \\
4\end{array}$ & $\begin{array}{c}0,56 \\
7\end{array}$ & 0,322 \\
\hline $\begin{array}{l}\text { Karakter } \\
\text { istik } \\
\text { Informa } \\
\text { si SAM }\end{array}$ & $\begin{array}{c}0,61 \\
0\end{array}$ & 0,121 & 4,543 & $\begin{array}{c}0,00 \\
0\end{array}$ & $\begin{array}{c}0,77 \\
3\end{array}$ & 0,598 \\
\hline
\end{tabular}

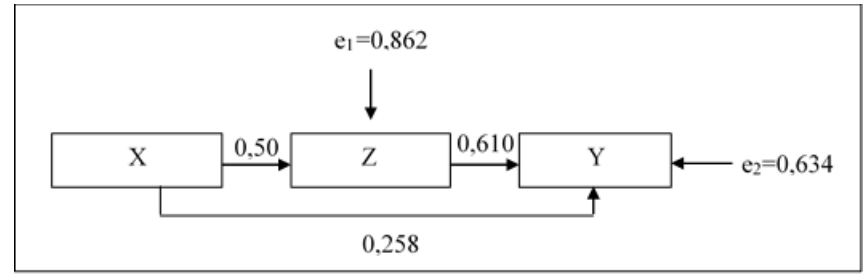

Gambar 4.5

\section{Analisis Intervening Strategi Mass Customization Terhadap Kinerja Perusahaan}

Berdasarkan hasil dari analisis jalur, dapat dilihat persamaan berikut:

$$
\begin{aligned}
& Z=0,507 X+e_{1} \\
& Y=0,258 X+0,610 Z+e_{2}
\end{aligned}
$$


Berdasarkan Gambar 4.5 dapat dilihat bahwa pengaruh langsung yang diberikan oleh variabel $\mathrm{X}$ terhadap $\mathrm{Y}$ adalah sebesar 0,258. Pengaruh tidak langsung $\mathrm{X}$ terhadap $\mathrm{Y}$ melalui $\mathrm{Z}$ adalah perkalian nilai beta $\mathrm{X}$ terhadap $\mathrm{Z}$ dengan nilai beta $\mathrm{Z}$ terhadap $\mathrm{Y}$, yaitu sebagai berikut:

Pengaruh langsung X ke Y $\quad=0,258$

Pengaruh tidak langsung $\mathrm{X}$ ke $\mathrm{Y}$

$\begin{array}{ll}\text { melalui Z } & =0,507 \times 0,610 \quad \\ \text { Total Pengaruh } & =0,309 \\ & =0,567\end{array}$

Berdasarkan perhitungan di atas dapat dilihat bahwa nilai pengaruh langsung $\mathrm{X}$ ke $\mathrm{Y}$ adalah sebesar 0,258 dan nilai pengaruh secara tidak langsung $\mathrm{X}$ ke $\mathrm{Y}$ melalui $\mathrm{Z}$ adalah sebebsar 0,309. Hal ini menggambarkan bahwa nilai pengaruh tidak langsung lebih besar dibandingakan dengan nilai pengaruh langsung. Oleh sebab itu, dapat disimpulkan bahwa secara tidak langsung $\mathrm{X}$ melalui $\mathrm{Z}$ memberikan pengaruh positif lebih besar terhadap $Y$.

Variabel intervenig dapat dikatakan signifikan apabila nilai $t_{\text {hitung }}>t_{\text {tabel }}$. Hasil perhitungan tersebut menyatakan bahwa $t_{\text {hitung }}>t_{\text {tabel }}$, dimana nilai $t_{\text {hitung }}$ adalah sebesar 2,621 dan nilai $t_{\text {tabel }}$ adalah sebesar 2,040. Berarti kesimpulannya adalah variabel intervening dapat dikatakan signifikan. Hal ini mengindikasikan bahwa variabel karakteristik informasi SAM yang bersifat broad scope signifikan menjadi variabel intervening antara hubungan strategi mass customization terhadap kinerja perusahaan.

Secara simultan dapat dilihat diketahui bahwa nilai $F_{\text {hitung }}$ adalah sebesar 22,335. Sedangkan nilai $F_{\text {tabel }}$ adalah sebesar 3,30. Berarti nilai $F_{\text {hitung }}>F_{\text {tabel. }}$. Oleh sebab itu dapat dinyatakan bahwa secara simultan variabel independen berpengaruh terhadap variabel dependen.

\section{Hipotesis 2}

Tabel 4.12

Hasil Analisis Regresi Pengaruh Strategi Mass

Customization Terhadap Kinerja Perusahaan

\begin{tabular}{|c|c|c|c|c|c|c|}
\hline $\begin{array}{c}\text { Koefisien } \\
\text { Regresi }\end{array}$ & Konstanta & thitung $_{\text {fig. }}$ & Sig. & $\mathrm{R}$ & $\begin{array}{c}\mathrm{R} \\
\text { Square }\end{array}$ & $\mathrm{F}_{\text {hitung }}$ \\
\hline 0,549 & 2,057 & 3,836 & 0,001 & 0,567 & 0,322 & 14,714 \\
\hline
\end{tabular}

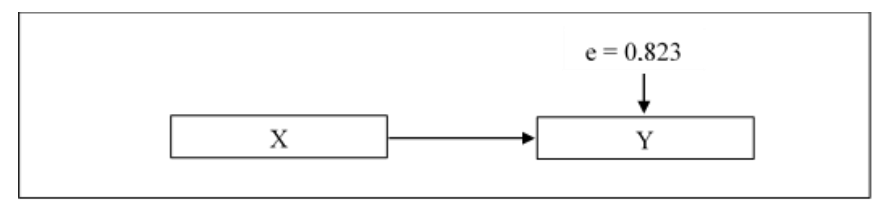

\section{Gambar 4.6}

\section{Analisis Regresi Pengaruh Strategi Mass Customization terhadap Kinerja Perusahaan}

Persamaan regresinya adalah sebagai berikut:

$$
\mathrm{Y}=2,057+0,549 \mathrm{X}
$$

Nilai $t_{\text {hitung }}$ adalah sebesar 3,836 dengan nilai signifikansi 0,001, dan nilai $t_{\text {tabel }}$ adalah sebesar 2,037. Artinya nilai $t_{\text {hitung }}>t_{\text {tabel }}$. Nilai signifikansinya adalah lebih kecil dari $0,05(0,001<0,05)$ dan koefisien regresinya bernilai positif yaitu sebesar 0,549 . Oleh sebab itu dapat disimpulkan bahwa terdapat pengaruh positif antara strategi mass customization terhadap kinerja perusahaan.

Besarnya pengaruh strategi mass customization terhadap kinerja perusahaan adalah sebesar 0,322. Hal ini mengindikasikan bahwa kinerja perusahaan dipengaruhi oleh strategi mass customization sebesar $32,2 \%$, sedangkan sisanya sebesar $67,8 \%$ dipengaruhi oleh faktor lain yang tidak ada dalam penelitian ini.

\section{Hipotesis 3}

Tabel 4.13

Hasil Analisis Regresi Pengaruh Strategi Mass Customization Terhadap Karakteristik Informasi SAM

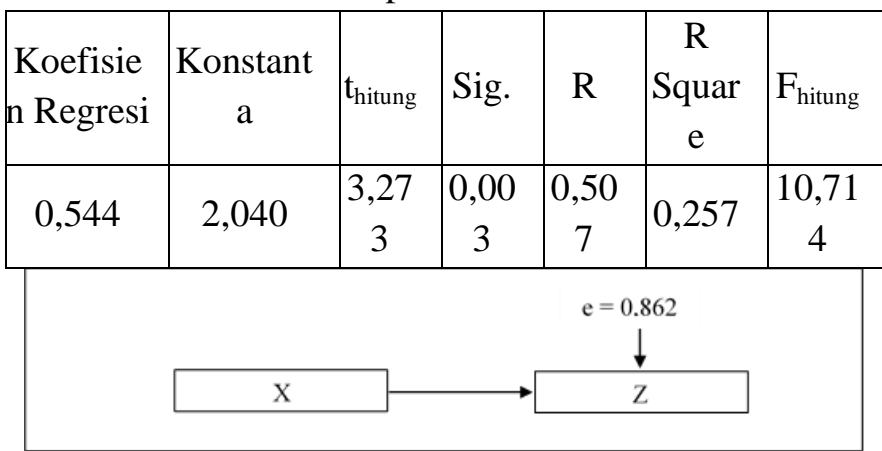

\section{Gambar 4.7}

\section{Analisis Regresi Pengaruh Strategi Mass}

Customization Karakteristik Informasi SAM

Persamaan regresinya adalah sebagai berikut:

$$
Z=2,040+0,544 X
$$

Nilai $t_{\text {hitung }}$ adalah sebesar 3,273 dengan nilai signifikansi 0,003, dan nilai tabel adalah sebesar 2,037. Artinya nilai $t_{\text {hitung }}>t_{\text {tabel. }}$. Nilai signifikansinya adalah lebih kecil dari $0,05 \quad(0,003<0,05)$ dan koefisien regresinya bernilai positif yaitu sebesar 0,544 . Oleh sebab itu dapat disimpulkan bahwa terdapat pengaruh positif antara strategi mass customization terhadap karakteristik informasi SAM. 
Besarnya pengaruh strategi mass customization terhadap kinerja perusahaan adalah sebesar 0,257. Hal ini mengindikasikan bahwa karakteristik informasi SAM dipengaruhi oleh strategi mass customization sebesar 25,7\%, sedangkan sisanya sebesar 74,3\% dipengaruhi oleh faktor lain yang tidak ada dalam penelitian ini.

\section{Hipotesis 4}

Tabel 4.14

Hasil Analisis Regresi Pengaruh Karakteristik

Informasi SAM Terhadap Kinerja Perusahaan

\begin{tabular}{|c|c|c|c|c|c|c|}
\hline $\begin{array}{c}\text { Koefisie } \\
\text { n Regresi }\end{array}$ & $\begin{array}{c}\text { Konstant } \\
\mathrm{a}\end{array}$ & $\mathrm{t}_{\text {hitung }}$ & Sig. & $\mathrm{R}$ & $\begin{array}{c}\mathrm{R} \\
\text { Squar } \\
\mathrm{e}\end{array}$ & $\mathrm{F}_{\text {tabel }}$ \\
\hline 0,668 & 1,501 & $\begin{array}{c}6,13 \\
9\end{array}$ & $\begin{array}{c}0,00 \\
0\end{array}$ & $\begin{array}{c}0,74 \\
1\end{array}$ & 0,549 & $\begin{array}{c}37,68 \\
5\end{array}$ \\
\hline & \multicolumn{5}{|c|}{$\begin{array}{c}\mathrm{e}=0.672 \\
\downarrow\end{array}$} \\
\hline
\end{tabular}

Gambar 4.8

Analisis Regresi Pengaruh Karakteristik Informasi

SAM terhadap Kinerja Perusahaan

Persamaan regresinya adalah sebagai berikut:

$$
\mathrm{Y}=1,501+0,668 \mathrm{Z}
$$

Nilai $t_{\text {hitung }}$ adalah sebesar 6,139 dengan nilai signifikansi 0,000, dan nilai $t_{\text {tabel }}$ adalah sebesar 2,037. Artinya nilai $t_{\text {hitung }}>t_{\text {tabel }}$. Nilai signifikansinya adalah lebih kecil dari $0,05 \quad(0,000<0,05)$ dan koefisien regresinya bernilai positif yaitu sebesar 0,668 . Oleh sebab itu dapat disimpulkan bahwa terdapat pengaruh positif antara karakteristik informasi SAM terhadap kinerja perusahaan.

Besarnya pengaruh karakteristik informasi SAM terhadap kinerja perusahaan adalah sebesar 0,549. Hal ini mengindikasikan bahwa kinerja perusahaan dipengaruhi oleh karakteristik informasi SAM sebesar $54,9 \%$, sedangkan sisanya sebesar $45,1 \%$ dipengaruhi oleh faktor lain yang tidak ada dalam penelitian ini.

\section{Pembahasan}

Analisis Pengaruh Penerapan Strategi Mass Customization Terhadap Kinerja Perusahaan Melalui Karakteristik Informasi SAM Yang Bersifat Broad Scope

Berdasarkan hasil analisis jalur ditemukan bahwa hipotesis 1 diterima. Dapat dilihat bahwa nilai pengaruh tidak langsung strategi mass customization terhadap kinerja perusahaan melalui karakteristik informasi SAM lebih besar dibandingan dengan nilai pengaruh langsung mass customization terhadap kinerja perusahaan. Oleh sebab itu, dapat disimpulkan bahwa secara tidak langsung mass customization melalui karakteristik informasi SAM memberikan pengaruh positif lebih besar terhadap kinerja perusahaan. Hasil penelitian ini sama selaras dengan hasil penelitian sebelumnya yang dilakukan oleh Abu Nizaruddin (2006), Syafira Ramadhea JR (2013), dan Edwin Setiawan (2015), yaitu strategi mass customization memberikan pengaruh signifikan positif terhadap kinerja perusahaan melalui informasi SAM yang bersifat broad scope.

Dalam upaya meningkatkan kinerjanya, perusahaan menggunakan strategi-strateginya tersendiri, salah satunya dalah strategi mass customization. Melalui strategi ini, perusahaan akan mampu menanggapi kebutuhan pelanggan dalam melakukan produsi barang dan jasa yang lebih variatif. Mass customizatin adalah bagian yang harus dipertimbangkan dalam membuat SAM guna menigkatkan kinerja perusahaan. SAM dapat dirancang guna memberikan informasi yang lebih maju yang akan memfasilitasi hubungan antar departemen yang bersifat fungsional. Dengan diterapkannya strategi mass customization ini diharapkan akan memberikan dampak yang baik terhadap tingkat kinerja perusahaan melalui informasi SAM.

\section{Analisis Pengaruh Penerapan Strategi Mass} Customization Terhadap Kinerja Perusahaan

Berdasarkan hasil uji regresi yang telah dilakukan dapat disimpulkan bahwa hipotesis 2 diterima. Dapat dilihat bahwa hubungan antara strategi mass customization terhadap kinerja perusahaan memiliki pengaruh positif. Hal ini tidak selaras dengan hasil penelitian sebelumnya yang dilakukan oleh Abu Nizaruddin (2006), Syafira Ramadhea JR (2013) dan Edwin Setiawan (2015). 
Banyak perusahaan manufaktur dan perusahaan jasa menghadapi permasalahan yang sama, yaitu pelanggan mengharapkan produk atau jasa yang khusus dikembangkapn untuk setiap pelanggan. Mass customization akan mengakibatkan suatu perusahaan melakukan produksi atas produk atau jasa yang lebih variatif yang menggabungkan keinginan-keinginan konsumen dengan lebih fleksibel tetapi biaya yang dikeluarkan lebih rendah tanpa ada perubahan kegiatan produksi yang ada. Mass customization merupakan strategi yang diharapkan bisa memberikan pengaruh terhadap kinerja perusahaan.

Analisis Pengaruh Penerapan Strategi Mass Customization Terhadap Karakteristik Informasi SAM Yang Bersifat Broad Scope

Berdasarkan hasil uji regresi yang telah dilakukan dapat disimpulkan bahwa hipotesis 3 diterima. Dapat dilihat bahwa hubungan antara strategi mass customization terhadap karakteristik informasi SAM memiliki pengaruh positif. Hal ini selaras dengan hasil penelitian sebelumnya yang dilakukan oleh Syafira Ramadhea JR (2013), Edwin Setiawan (2015), dan Abu Nizaruddin (2005).

Informasi SAM sangat diperlukan dan juga dibutuhkan oleh para manajer dalam mencari serta menemukan pemikiran atau ide-ide terbaru guna memproduksi produk-produk terbarunya. Informasi SAM bisa menimbulkan peningkatan total alternatif sebagai bahan pertimbangan manajer dalam pengambilan keputusan secara simultan yang berhubungan dengan input serta output yang tidak pasti. Informasi yang bersifat broad scope sangat dibutuhkan oleh manajer guna menemukan dan menentukan inovasi-inovasi bagaimana dapat membuat produk baru atau jasa baru. Oleh karena itu, informasi SAM yang bersifat broad scope sangat diperlukan saat suatu perusahaan menerapkan strategi mass customization.

Analisis Pengaruh Karakteristik Informasi SAM yang Bersifat Broad Scope Terhadap Kinerja Perusahaan

Berdasarkan hasil uji regresi yang telah dilakukan dapat disimpulkan bahwa hipotesis 4 diterima. Dapat dilihat bahwa hubungan antara karakteristik informasi SAM yang bersifat broadscope terhadap kinerja perusahaan memiliki pengaruh positif. Hal ini selaras dengan hasil penelitian sebelumnya yang dilakukan oleh Syafira Ramadhea JR (2013), Edwin Setiawan (2015), Abu Nizaruddin (2005).

Informasi SAM sangat membantu bagi pihak perusahaan dalam menghadapi berbagai rintangan dan tantangan pasar yang sangat kompetitif serta dapat membantu para manajer memantau kinerja perusahaan. Informasi yang diberikan oleh SAM dalam teori teknis rasional, terutama dalam organisasi pemerintah, dapat membantu alokasi sumber daya secara efisien dan efektif. Manajer sering tidak menyadari buruknya kinerja perusahaan, sehingga perusahaan terlanjur masuk ke dalam zona krisis yang dianggap serius. Oleh karena itu, dibutuhkan strategistrategi oleh manajer untuk menghindari kondisi tersebut.

\section{Pembahasan Komentar Responden terhadap Objek Penelitian \\ Strategi Mass Customization}

Sebagian besar responden berkomentar tentang strategi mass customization. Secara umum responden yang berkomentar tentang strategi mass customization berperndapat bahwa strategi mass customization memberikan dampak yang baik terhadap perkembangan perusahaan. Dalam menjalankan usaha biro wisata, khususnya penjualan paket wisata kepada para konsumen, pihak perusahaan biro wisata memang menerapkan strategi ini sejak lama. Namun ada beberapa perusahaan yang mengaku baru mengetahui nama strategi ini yaitu strategi mass customization, padahal mereka telah lama menggunakan strategi ini.

\section{Karakteristik Informasi SAM yang Bersifat Broad Scope}

Beberapa responden mengaku informasi SAM (broad Scope) dibutuhkan dalam pemasaran paket wisata. Responden mengaku bahwa informasi yang bersifat ekonomi dan nonekonomi dibutuhkan oleh perusahaan biro wisata. Informasi nonekonomi yang dibutuhkan perusahaan antara lain informasi tentang selera pelanggan, informasi mengenai ancaman pesaing, informasi eksternal perusahaan, perkembangan teknologi, dan relasi kerja.

\section{Kinerja Perusahaan}

Komentar mengenai kinerja perusahaan adalah komentar yang paling sedikit diberikan oleh 
responden. Rata-rata responden yang berkomentar tentang kinerja perusahaan pasti menghubungkan dengan strategi mass customization dan karakteristik informasi SAM. Responden mengaku kinerja perusahaannya meningkat setelah menerapkan strategi mass customization. Kinerja perusahaan juga lebih baik dengan adanya teknologi-teknologi yang berkembang.

\section{Kesimpulan, Keterbatasan Dan Saran Kesimpulan}

Berikut adalah kesimpulan penelitian ini sesuai hasil analisis dan pembahasan yang telah dijelaskan sebelumnya:

1) Secara tidak langsung mass customization melalui karakteristik informasi SAM memberikan pengaruh positif lebih besar terhadap kinerja perusahaan.

2) Strategi mass customization memberikan pengaruh positif terhadap kinerja perusahaan. Hal ini mengindikasikan dengan diterapkannya strategi mass customization mampu meningkatkan kinerja perusahaan biro wisata di kota Banda Aceh.

3) Strategi mass customization memberikan pengaruh positif terhadap karakteristik informasi SAM. Hal ini mengindikasikan bahwa dengan diterapkan strategi mass customization pada perusahaan biro wisata di Kota Banda Aceh akan mempengaruh informasi-informasi yang dibutuhkan oleh manajer, dalam hal ini adalah informasi SAM yang bersifat broad scope.

4) Karakteristik informasi SAM yang bersifat broadscope memberikan pengaruh positif terhadap kinerja perusahaan. Hal ini mengindikasikan bahwa kinerja perusahaan biro wisata di Kota Banda Aceh meningkat dengan adanya informasi SAM yang bersifat broad scope.

\section{Implikasi Penelitian}

Berdasarkan hasil dari komentar responden dapat diketahui bahwa strategi bisnis, salah satunya strategi mass customization, sangat penting bagi perusahaan biro wisata. Pemilik dan manajer perusahaan tentu menginginkan kinerja perusahaannya terus meningkat. Dengan diterapkan strategi tersebut, responden mengaku kinerja perusahaannya meningkat dan mereka jarang menerima keluhan dari pelanggan. Dalam menerapkan strategi mass customization tentu dibutuhkan informasi-informasi, salah satunya adalah informasi SAM yang bersifat broad scope agar keinginan dan kebutuhan pelanggan dapat dipenuhi.

\section{Keterbatasan}

Dalam melakukan penelitian ini penliti mengalami beberapa keterbatasan, diantaranya sebagai berikut:

1) Peneliti mengalami kesulitan dalam memperoleh data saat membagikan kuesioner kepada responden. Hal ini disebabkan oleh responden yang tidak ada di kantor biro wisata dan responden sering berangkat ke luar kota dalam rangka memberikan pelayanan kepada pelanggannya.

2) Keterbatasan waktu yang dimiliki oleh responden sehingga membuat proses pengumpulan data sedikit lebih lama.

3) Pengumpulan data dalam penelitian ini melalui kuesioner membuat tidak menutup kemungkinan adanya persepsi responden yang berbeda dengan keadaan yang sebenarnya.

\section{Saran}

\section{Saran Praktis}

Saran praktis yang dapat diberikan oleh peneliti antara lain adalah sebagai berikut:

1) Kepada para manajer dan atau pemilik perusahaan biro wisata diharapkan agar terus mengutamakan kepuasan konsumen guna meningkatkan kinerja perusahaan. Sesuai dengan hasil penelitian ini bahwa salah satu strategi yang mempengaruhi kinerja perusahaan adalah strategi mass customization, dimana strategi tersebut diterapkan dengan tujuan untuk memenuhi permintaan pelanggan yang berfariatif.

2) Kepada para manajer dan atau pemilik perusahaan biro wisata diharapkan lebih sensitif dengan keinginan konsumen dan informasiinformasi yang mempengaruhi kinerja perusahaan di masa yang akan datang. 


\section{Saran Akademis}

Saran akademis yang dapat diberikan oleh peneliti antara lain adalah sebagai berikut:

1) Penelitian selanjutnya diharapkan dapat menambahkan variabel independennya atau memakai variabel lain yang dapat mempengaruhi kinerja perusahaan.

1. Pada penelitian berikutnya diharapkan apabila memungkinkan menggunakan metode wawancara langsung dengan responden.

\section{Daftar Pustaka}

Ayu, G., \& Dahen, L. D. (2014). Pengaruh Karakteristik Informasi Sistem Akuntansi Manajemen Terhadap Kinerja Manajerial Studi Empiris pada PT Bank Perkreditan Rakyat di Kabupaten Tanah Datar. Journal of Economic and Economic Education, 3(1), 89-94. https://doi.org/https://doi.org/10.22202/economi ca.2014.v3.i1.250

Balakrishnan, S. (1996). Benefits of Customer and Competitive Orientations in Industrial Markets. Industrial Marketing Management, 269(655), 257-269.

Bouwens, J., \& Abernethy, M. A. (2000). The consequences of customization on management accounting system design. Accounting, Organizations and Society, 25(3), 221-241. https://doi.org/10.1016/S0361-3682(99)00043-4

Dinas Pariwisata Kota Banda Aceh. (2016). Daftar Travel.

Dinas Pariwisata Kota Banda Aceh. (2018). Daftar Travel Agent. Kota Banda Aceh.

Eliana. (2015). Pengaruh sistem akuntansi manajemen dan audit internal terhadap kinerja manajerial (studi kasus Lembaga Keuangan Mikro di Banda Aceh). Universitas Syiah Kuala.

Ernawati. (2005). Pengaruh Strategi Bisnis dan Ketidakpastian Lingkungan terhadap Hubungan antara Informasi Broad Scope Sistem Akuntansi Manajemen dan Kinerja Manajerial. Jurnal Akuntansi Dan Investasi, 6(1), 21-39.

Fahmi, I. (2010). Manajemen Kinerja (Teori dan Aplikasi). Bandung: Alfabeta, Cv.

Ghasemi, R., Mohamad, A. N., Karami, M., \& Bajuri, N. H. (2016). The Mediating Effect of Management Accounting System on the Relationship between Competition and Managerial Performance. International Journal of Accounting \& Information Management, 24(3). https://doi.org/10.1108/IJAIM-05-2015$\underline{0030}$

Gordon, L. A., \& Narayanan, V. K. (1984). Management Accounting Systems, Perceived
Environmental Uncertainty and Organization Structure: An Empirical Investigation. Ayu, G., \& Dahen, L. D. (2014). Pengaruh Karakteristik Informasi Sistem Akuntansi Manajemen Terhadap Kinerja Manajerial Studi Empiris pada PT Bank Perkreditan Rakyat di Kabupaten Tanah Datar. Journal of Economic and Economic Education, 3(1), 89-94. https://doi.org/https://doi.org/10.22202/economi ca.2014.v3.i1.250

Hansen, D. R., \& Mowen, M. M. (2004). Management Accounting (Akuntansi Manajemen) (7th ed.). Jakarta: Salemba Empat.

Hery. (2014). Controllership. Jakarta: Grasindo.

Heryanto, G., \& Augustine, Y. (2017). The Influence of Organizational Culture on Corporate Performance:Using Management Accounting System as the Mediating Variable. OIDA International Journal of Sustainable Development, 10(1).

Heryanto, I., \& Triwibowo, T. (2018). Path Analysis Menggunakan SPSS dan Excel. Bandung: Informatika.

Indriani, M., \& Nadirsyah. (2015). Interaction Effect Of Budgetary Participation And Management Accounting System On Managerial Performance: Evidence From Indonesia. Global Journal of Business Research, 9(1), 1-13.

JR, S. R. (2013). Pengaruh Strategi Cistomization terhadap Kinerja Perusahaan Melalui Penggunaan Karakteristik Informasi Sistem Akuntansi Manajemen (Studi Empiris pada Perusahaan Manufaktur di Kota Padang). Jurnal Akuntansi, 1(1).

Laitinen, E. K. (2008). A Portfolio Approach to Develop a Theory of Future Management Accounting Systems. EuroMed Journal of Business, 3(1), 23-37. https://doi.org/10.1108/14502190810873803

Mia, L., \& Chenhall, R. H. (1994). The Usefulness of Management Accounting Systems, Functional Differentiation and Managerial Effectiveness. Accounting, Organizations and Society, 19(1), $1-13$.

Nazaruddin, I., \& Fajry, S. (2005). Pengaruh Customization dan Interdependensi terhadap Karakteristik Informasi Sistem Akuntansi Manajemen Broad scope dan Aggregation. Jurnal Akuntansi Dan Investasi, 6(1), 94-113.

Nizarudin, A. (2006). Pengaruh Strategi Customization Terhadap Kinerja Perusahaan Melalui Penggunaan Karakteristik Informasi Sistem Akuntansi Manajemen yang Bersifat Broad Scope dan Aggregation. Simposium Nasional Akuntansi 9 Padang, 23-26. 
Putri, L. K. (2014). Pengaruh Ketidakpastian Lingkungan dan Strategi Bisnis Terhadap Kinerja Manajerial dengan Karakteristik Sistem Akuntansi Manajemen Sebagai Variabel Intervening. Jurnal Akuntansi, 2(2), 1-17.

Santos, L. L., Gomes, C., \& Arroteia, N. (2012). Management Accounting Practices in The Portuguese Lodging Industry. Journal of Modern Accounting and Auditing, 8(1), 1-14.

Sanusi, A. (2011). Metodologi Penelitian Bisnis. Malang: Salemba Empat.

Serambinews.com. (2018). Pariwisata Jadi Sektor Unggulan, Aceh Target 100 Ribu Wisman.

Setiawan, E. (2015). Pengaruh Strategi Customizationterhadap Kinerja Perusahaan melalui Penggunaan Karakteristik Informasi Sistem Akuntansi Manajemen (Studi Empiris pada Perusahaan Manufaktur di Provinsi Riau). Jurnal Online Mahasiswa, 2(1), 1-15.

Sumolang, J. H. (2015). Pengaruh Teknologi Informasi dan Saling Ketergantungan Terhadap Kinerja Manajerial dengan Karakteristik Sistem Akuntansi Manajemen sebagai Variabel Intervening. Jurnal Online Mahasiswa Ekonomi Universitas Riau, 2(1), 1-13.

Syam, F., Azzumar, \& Zuraida. (2018). Influence of Characteristics of Management Accounting Information Systems to Managerial Performance with Variables of Business Strategy Modernations and Uncertainty Duties in Banking Companies in Aceh Province Influence of Characteristics of Management Ac. International Journal of Academic Research in Business \& Social Sciences, 8(7), 238-256. https://doi.org/10.6007/JJARBSS/v8-i7/4339

Walker, K. B., Fleischman, G. M., \& Johnson, E. N. (2012). Measuring Management Accounting Service Quality. Management Accounting Quarterly, 13(3), 15-27.

Wibowo. (2007). Manajemen Kinerja (5th ed.). Depok: Rajagrafindo Persada. Accounting, Organizations and Society, 9(1), 33-47. 